\title{
Scaffolding Reading Comprehension Skills
}

\author{
Ashraf Atta Mohamed Safein Salem ${ }^{1}$ \\ ${ }^{1}$ Department of Languages \& Linguistics, College of Business Administration, Sadat Academy for Management \\ Sciences, Egypt \\ Correspondence: Ashraf Atta Mohamed Safein Salem, Department of Languages \& Linguistics, College of \\ Business Administration, Sadat Academy for Management Sciences, Egypt. E-mail: sirashrafams@hotmail.com
}

\author{
Received: November 23, 2016 Accepted: December 22, 2016 Online Published: December 24, 2016 \\ doi: 10.5539/elt.v10n1p97 \\ URL: http://dx.doi.org/10.5539/elt.v10n1p97
}

\begin{abstract}
The current study investigates whether English language teachers use scaffolding strategies for developing their students' reading comprehension skills or just for assessing their comprehension. It also tries to demonstrate whether teachers are aware of these strategies or they use them as a matter of habit. A questionnaire as well as structured interviews were basically designed for the purpose of the study. The descriptive qualitative research design was adopted due to suitability for the nature of the study. Results of the study revealed that Non-native English language teachers are not aware of the nature of scaffolding strategies they use; they use such strategies for the purpose of assessing their students' comprehension rather than scaffolding their comprehension. It is recommended that English language teachers have an adequate orientation of the nature of scaffolding strategies, to what extent to be used (when to begin using these strategies and when to stop using them) and the significance in developing comprehension skills of students in the mainstream schools.
\end{abstract}

Keywords: scaffolding strategies, reading comprehension, non-native English language teachers

\section{Introduction}

Reading is an essential skill for academic success (Levine, Ferenz, \& Reves 2000). Hence, it is a perquisite to almost all graduate programs however most students suffer from deficiencies in reading (Farhady \& Sajadi, 1999). It is not only a useful skill in academic contexts but it is also crucial for daily life as people read to get information about specific topics (Farhady, 2005, p. 1). Traditionally, reading is viewed as a passive receptive skill that happens in a separate environment. In the process of reading, readers usually respond to the meaning of words and sentences (Pressley, El-Dinary, Wharton-McDoland, and Brown as cited in Royanto, 2012). Reza and Mahmood (2013) points out, it was viewed as "a purely individualistic skill that has been looked from a completely different perspective “(p. 67).

Readers depend mainly on their background knowledge and the wide vocabulary stock they have in order to understand the reading materials as well as making logical conclusions (Reed, 1982; French, Ellsworth, \& Amoroso, 1995). This repertoire of knowledge which is referred to as a "schemata" helps in representing meaning in the connected discourse (Anderson, Spiro, \& Anderson, 1977). A recent viewpoint of reading was proposed by Lev Vygotsky (1978) through the socio-cultural theory of learning (Lantolf 2006; Remi \& Lawrence, 2012). In the light of such theory, reading is viewed as a social skill that requires an active participation, interaction and involvement of learners (Reza \& Mahmood, 2013).

Two main metaphors lay behind Vygotsky's work in the socio-cultural theory in learning; scaffolding and Zone of Proximal Development (ZPD). ZPD represents a pivotal concept in the socio-cultural theory that explicates the important role of teachers as mediators; it's the heart of the concept of scaffolding (Clark \& Graves, 2004; Huong, 2003; Kozulin, 2004; Lantolf \& Poehner, 2008; Lantolf \& Thorne, 2006, Reza \& Mahmoud, 2013). ZPD is referred to as:

What an individual can accomplish when working in collaboration with others versus what he or she could have accomplished without collaboration with others (Zuengler \& Miller 2006, p. 39).

ZPD is the core element of Vygotsky's theory as it refers to a distinguishing point between students' performance when they are not guided or helped by other people. Logically, students' performance when guided to some extent by their tutors or teachers outpowers performance of their counterparts who do not receive any help and guidance. 
The essence of help, guidance and monitoring represents the core of the second metaphor proposed by Wood, Bruner and Ross (1976) in their examination of parent-child talk in the early years (Gibbons, 2002). It is really an excellent metaphor for describing strategies used for helping and guiding students to learn high-order thinking skills, it is referred to as scaffolding strategies. Building workers in under construction need scaffolds to help them to do certain tasks and to reach high places. Hence, scaffolds are temporary, used to achieve certain tasks then they should be removed. In educational contexts, instructional scaffolds are temporarily used to help and guide students to learn and practice skills such as the language skills. These scaffolds are gradually removed bit by bit in order to allow student to feel independence from teacher's surveillance and control to feel free to learn on their own.

Scaffolding can be provided by experts as well as more experienced people around the student; teachers, parents, and even peers at the same class. Yet, planned instructional scaffolds are often provided by teachers (Benson, 1997; Lipscomb, Swanson, \& West, 2004; Haghparast \& Mall-Amiri, 2015). Well-constructed Scaffolds optimize student learning, provide a supportive environment as well as facilitating student independence. Scaffolding strategy refers to supporting students to certain extent until the degree of acquiring new skills in an individual basis (Rosenshine \& Meister, 1992; Lorkin, 2002). Scaffolding lasts not forever, it stops once students are able to do tasks which are beyond their current capabilities. Teacher's comments and feedback provide students with desire to take responsibility of their learning and to create independence from their teachers' continuous care. Scaffolding strategies represent abridge that helps people to go from one secure place to another secure one alongside dangerous places; it is a tool rather than a goal itself.

In addition, scaffolding secures opportunities for students to learn how to solve problems, do certain tasks, and transform information rather than just memorize certain scenarios to undertake some actions (Poorahmadi, 2009). Scaffolding reaches climax at the very beginning and decrease gradually till it is ceased as students' ability increases and they become more independent and the gap is filled (Berk, 2002; Krause, Bochner, \& Duchens, 2003; McDevitt \& Ormond, 2002). Therefore, instructional scaffolds are of paramount importance in language learning especially in Learning reading comprehension (Huggins \& Edwards, 2011) because reading is viewed as a problem solving behavior that gets readers involved in a process of meaning derivation from connected discourse of written materials (Poorahmadi, 2009).

In the reading process, readers draw on contextual information containing syntactic, semantic and discourse constraints that affect their interpretation of the text (Rivers, 1988). Hence, students need teacher assistance, rather say instructional scaffolds, to understand and to comprehend the message lying behind the reading tasks.

Reading comprehension is referred to as a cognitively demanding skill involving careful attention, memory, perceptual processes and comprehension processes (Chastain, 1988). Reading comprehension is "an intentional, active, interactive process that occurs before, during and after a person reads a particular piece of writing "(Brummitt-Yale, 2008, p. 2). Reading comprehension requires more than knowledge of vocabulary and syntax, rather it needs the ability to perceive the exact nature of the passage being communicated. Therefore, students have to understand implicit facts or what is written "between the lines", they also must learn to detect moods, intentions as well as factual details" (Papalia, 2006).

Basically reading is a process of interaction among three triangular components; the text, the reader, and the purposes of reading (Hunghes, 2007). Reading comprehension involves "extracting and constructing meaning through interaction and involvement with reading text" (Snow, 2002).

Instructional scaffolds foster reading comprehension skills (Duffy, 2002; Duke \& Pearson, 2002; Palinscar, 2003; Pressley, 2002). Through scaffolding processes, readers acquire a broader perspective of reading materials to improve their comprehension (Clark \& Graves, 2004). Instructional scaffolds also play a pivotal role in facilitating reading which ensures comprehension or understanding independently (Many, 2002; Mayer, 1993). Hence, it is necessity for comprehension to happen because reading action "cannot be called without comprehending" (Karasakaloglu, 2010, p. 222).

Beside cognitive scaffolding strategies, teachers should pay a due attention to the metacognitive skills. Cognitive strategies relate closely to the content or the information presented whereas metacognitive strategies refer to the process of monitoring or reflecting on these cognitive strategies.

Metacognition refers to the ability to think about thinking, select appropriate problem-solving strategies and monitor using such skills in various contexts (Flavell, 1979). Self-regulated learning is closely related with such metacognitive strategies that learners use in order to achieve desired learning outcomes (Lajoie, 2008). Metacognition relates with high learning outcomes and is among the influences that have had the greatest impact on achievement (McCurdy, Naismith, \& Lajoie, 2010; Hattie, 2009) in various disciplines and domains such as 
reading, writing, and mathematics (Bransford, Brown, \& Cocking, 2000).

Despite the necessity of involving metacognitive strategies in the reading lessons for helping students understand the reading material, there is a challenge to use such strategies in the time allowed in regular classrooms which doesn't exceed 40 minutes especially in overcrowded classes.

Non-native English language teachers use scaffolding strategies for developing reading comprehension skills intuitively (Cheyne \& Tarulli, 1999; Koda, 2005; Van Der Stufy, 2002) in a random way, meanwhile, it should be presented reasonably and systematically in order to promote cognitive development (Donovan \& Smolkin, 2002). Non-native English Language teachers sometimes use scaffolding strategies unconsciously without even being aware of its nature. However, pre-planned instructional scaffolding process helps students to be responsive and involved in the classroom activities (Many, 2002; Roehler \& Cantlon, 1997).

Several studies have been conducted to investigate the literacy teachers' use of scaffolding strategies for developing reading comprehension skills (Taylor, Pearson, Clark, \& Walpole, 2000; Wharton-McDonald, Pressley, \& Hampston, 1998) as well as pre-service teachers (Many et al., 2007).

Non-native English Language teachers in mainstream schools in the Middle-East are not qualified enough to use up-to-date teaching innovations. Four-year university academic preparation seems to be inadequate with no further professional growth or in-service training. Hence, Non-native English language teachers in Arab countries are rarely aware of the modern teaching strategies and therefore don't tend to apply such modern teaching methods or follow the latest innovations in their teaching practice. Hence, Non-native English Language teachers are not aware of the nature of scaffolding strategies even though they use them intuitively within the classroom. Therefore, the current study aims to answer the following question:

"To what extent do Non-native English Language teachers use cognitive and metacognitive Scaffolding strategies for developing Reading comprehension skills?"

From this main question, there following sub-questions are derived:

- To what extent do Non-native teachers of English in intermediate schools use scaffolding strategies to enhance reading comprehension skills of their students?

- Do Non-native teachers of English use such scaffolding strategies to enhance reading comprehension skills or to evaluate these skills?

- Do Non-native teachers of English use such scaffolding strategies consciously or as a matter of habit?

- Are there any statistically significant differences in the mean scores of Non-native teachers of English use of scaffolding strategies based on their gender, years of experience, the amount of teaching and qualification?

- What are the implications of using well developed instructional scaffolds in reading classes?

In order to ensure ecological validity, naturalistic extracts of scaffolding strategies, open-ended questions at the end of the questionnaire are used to illustrate effective use of scaffolding strategies in order to enhance reading comprehension in English language in the Egyptian mainstream schools. Question (1) will be answered through statistical analysis of the questionnaire items provided to the Non-native teachers of English in the intermediate schools. Question (2) will be addressed by analyzing the descriptive statistics of teachers reports on their actual performance in the classroom based on their self-reports, structured interviews and the researcher observation. Question (3) relates to the implications of Non-native teachers of English use of scaffolding strategies in enhancing such strategies which will be explored in the final discussion.

\section{Method}

This is a qualitative study of teachers' practices inside the classroom. An eclectic approach is used to explore Non-native teachers of English use of scaffolding strategies which can be done through the means of a questionnaire, their purpose of using such scaffolding strategies i.e. whether teachers use such scaffolding strategies to enhance reading comprehension skills or to evaluate these skills, which can be assessed through observation, structured interviews as well as teachers' self-report.

\subsection{Sampling Procedures}

The sample of the study consists of (94) Non-native English language teachers in the intermediate schools in Alexandria Governorate. Teaching load decreases as teachers are promoted to higher levels i.e. senior teachers teach only (6) sessions a week whereas newly recruited teachers work for (12) or (18) classes a week. Teachers are hired after (4) years university preparation at the faculty of Education, Arts, or Alsun. Some teachers complete their diploma, masters and PhD studies whether inside or outside Egypt to promote for higher levels 
and have more professional growth hand in hand with attending the training courses and workshops while serving.

Table 1. Profile of the study sample

\begin{tabular}{lllll}
\hline & & N. & Percentage & Cumulative percent \\
\hline Gender & Male & 56 & 59.6 & 59.6 \\
Qualification & Female & 38 & 40.4 & 100.0 \\
& B.A. & 87 & 92.6 & 92.6 \\
Job & Masters & 7 & 7.4 & 110.0 \\
Years of Experience & Teachers & 92 & 97.7 & 97.9 \\
& Senior teachers & 2 & 2.1 & 100.0 \\
\multirow{3}{*}{ Teaching Load } & 1-10 years & 59 & 62.8 & 62.8 \\
& 10-20 years & 22 & 23.4 & 86.2 \\
& More than 20 Years & 13 & 13.8 & 100.0 \\
& 6 periods & 2 & 2.1 & 2.1 \\
& 12 periods & 83 & 88.3 & 90.4 \\
& 18 periods & 9 & 9.6 & 100.0 \\
\hline
\end{tabular}

\subsection{Measures and Covariates}

Due to the qualitative nature of this study, three main tools have been used in the current study; a questionnaire, self-reports, observation sheet and structured interviews with the teachers. The latter three tools were selected according to the chart prepared by Clark and Graves (2005) with significant reliability. The observation sheets as well as the structured interviews include both cognitive and metacognitive scaffolding strategies similar to those of the questionnaire in order to illustrate the purpose behind using scaffolding strategies whether for enhancing comprehension or to assess comprehension skills. Interviews are mainly intended to explore whether teachers are aware of using such strategies or that it is used unconsciously. The questionnaire was designed to explore the extent of Non-native teachers of English in the intermediate schools using scaffolding strategies to enhance reading comprehension skills of their students.

\subsection{Description of the Questionnaire}

A self-report questionnaire was designed, the subjects of the sample first language is Arabic. The questionnaire consists of (28) statements to which the teachers responded on a five-point scale (from "often use" to "never use"). The questionnaire items fall under eight main scales that can be explained as follows:

1) Monitoring comprehension strategies: It refers to the use of monitoring strategies to promote comprehension. It has seven positively-worded statements that reflect using such strategies in the pre-reading, while-reading and post-reading (Max. score 35).

2) Cooperative learning strategies: This scale refers to using cooperative strategies in order to enhance reading comprehension skills. It has five positively-worded statements (Max. score 25) would reflect keeping on using such strategies for teaching each lesson.

3) Using graphic organizers: It refers to using graphic organizers in order to enhance reading comprehension skills. It has (2) positively-worded statements (Max. score 10).

4) Answering comprehension questions: It refers to using compression questions in order to enhance reading comprehension skills. It has (2) positively-worded statements (Max. score 10).

5) Summarizing strategies: It refers to using summarizing strategies in order to enhance reading comprehension skills. It has (2) positively-worded statements (Max. score 10).

6) Using multiple teaching strategies: This scale refers to using multiple teaching strategies in order to enhance reading comprehension skills. It has (2) positively-worded statements (Max. score 10).

7) Strategies based on cognitive scaffolding strategies: This scale refers to using strategies based on cognitive scaffolding strategies in order to enhance reading comprehension skills. It has (3) positively-worded statements (Max. score 10). 
8) Use of metacognitive strategies: This scale refers to using metacognitive strategies in order to enhance reading comprehension skills. It has (5) positively-worded statements (Max. score 10).

\subsection{Reliability and Validity of the Questionnaire}

In order to investigate the reliability of the questionnaire, Cronbach Alpha, split-half method, and Guttmann reliability coefficients were computed. Cronbach Alpha reliability coefficient was $(0.649)$ with the number of items in the questionnaire is (28) items divided into two main parts; cognitive and metacognitive scaffolding strategies. This coefficient refers to a high degree of reliability as it is close to the plus one.

Internal consistency validity coefficients showed that the questionnaire is valid for assessing the teachers' use of scaffolding strategies in enhancing students reading comprehension skills. Close inspection of the following table makes it clear that the questionnaire is valid for use with Non-native teachers of English in the eight dimensions.

Table 2. Internal consistency validity of the questionnaire

\begin{tabular}{ll}
\hline Scales & Correlation Coefficients \\
\hline 1) Monitoring comprehension strategies & $.462^{* *}$ \\
2) Cooperative learning strategies & $.711^{* *}$ \\
3) Using graphic organizers & $.449^{* *}$ \\
4) Answering comprehension questions & $586^{* *}$ \\
5) Summarizing strategies & $663^{* *}$ \\
6) Using multiple teaching strategies & $453^{* *}$ \\
7) Strategies based on cognitive scaffolding strategies & $.364^{* *}$ \\
8) Use of Metacognitive strategies & $.149^{* *}$ \\
\hline
\end{tabular}

\subsection{Procedure}

To answer the first question: "To what extent do Non-native teachers of English use scaffolding strategies in intermediate schools to enhance reading comprehension skills of their students?, and the second question: "Do Non-native teachers of English use such scaffolding strategies to enhance reading comprehension skills or to evaluate these skills?, as well as the the question: " Are there any statistically significant differences in the mean scores of Non-native teachers of English use of scaffolding strategies based on their gender, experiences, teaching loads and qualification?, scaffolding strategies use questionnaire has been designed.

With regard to the question, do Non-native teachers of English use such scaffolding strategies consciously or as a matter of habit? An observation sheet (format) was dsigned and used. The observation process took place in actual classes through the form that is given in Appendix (A).

\section{Results}

The collected data on the eight measures/variables were tabulated then totaled in order to get the percentage of students choosing each statement (total=28) in each scale (1-8). The responses revealed that a large amount of Non-native teachers of English use scaffolding strategies. Table 3 reflects the percentages on a two-point scale (never/rarely use vs. usually/often use scaffolding strategies), and Table 4 reflects the percentages on a five-point scale (never, rarely, do not know, usually and often use scaffolding strategies).

All sub-scales were treated on an equal footing as none of them include negative items, the researcher has deleted all the negative items from all scales as it was clear from the pilot administration of the questionnaire that negative items have led to lack of clear orientation and adversely affect their understanding of the scale.

Table 3 reveals that large number of Non-native English language teachers use scaffolding strategies in their sessions for enhancing reading comprehension skills. Interestingly, the fourth scale "answering comprehension questions" rated the highest among all scales which represents a safeguard for the learners to develop their reading comprehension skills. The second ranked scale is teacher use of summarizing strategies so as to help students focus on the main ideas, $81.71 \%$ of the sample reported using such strategies. A large amount of Non-native English language use graphic organizers to help their students to visualize the abstract facts and concepts in an organized way. With regard to the seventh scale "using techniques and approaches based on cognitive scaffolding strategies", it rates the lowest among all scales especially teachers working for a long time with little professional growth. 
Hence, those teachers are not aware of techniques and approaches depending on scaffolding strategies such as WebQuest and Reciprocal Teaching approach.

Table 3. Results of survey in percentages (two-point scale) $(\mathrm{N}=94)$

\begin{tabular}{|c|c|c|c|c|}
\hline Scales & $\begin{array}{l}\text { Never Use } \\
\text { Strategies }\end{array}$ & Scaffolding & $\begin{array}{l}\text { Often Us } \\
\text { Strategies }\end{array}$ & Scaffolding \\
\hline & $N$. & $\%$ & $N$. & $\%$ \\
\hline 1) Monitoring comprehension strategies & 117 & 17.78 & 465 & 70.69 \\
\hline 2) Cooperative learning strategies & 58 & 12.34 & 329 & 70 \\
\hline 3) Using graphic organizers & 22 & 11.70 & 146 & 77.66 \\
\hline 4) Answering comprehension questions & 5 & 2.66 & 158 & 84.04 \\
\hline 5) Summarizing strategies & 9 & 4.78 & 154 & 81.91 \\
\hline 6) Using multiple teaching strategies & 19 & 10.11 & 136 & 72.34 \\
\hline $\begin{array}{l}\text { 7) Techniques and approaches based on } \\
\text { cognitive scaffolding strategies }\end{array}$ & 54 & 19.15 & 149 & 52.84 \\
\hline 8) Use of Metacognitive strategies & 61 & 12.98 & 350 & 74.47 \\
\hline
\end{tabular}

Close inspection of Table 4 reveals that very few Non-native English language teachers never use such scaffolding strategies in order to enhance reading comprehension skills. The amount of teachers who keep using such strategies all the time is relatively high compared with those teachers who use such strategies now and then. It is goes without saying that using metacognitive scaffolding strategies for helping students to develop their reading comprehension skills was used to some extent compared with the cognitive strategies with a total percentage (74.47\%). Pintrich (2002) asserts that "students who know about the different kinds of strategies for learning, thinking, and problem solving will be more likely to use them" (p. 222). According to Zohar and David (2009), there must be a "conscious meta-strategic level of higher order thinking." (p. 179).

Table 5 indicates that more than two-thirds of Non-native English language teachers use scaffolding strategies in order to enhance reading comprehension skills to achieve comprehension $(77.66 \%)$ for using metacognitive strategies and from $(75.53 \%)$ to $(62.32 \%)$ for other cognitive strategies rather than to assess the teaching product after finishing the teaching process (16.81\%) for using metacognitive strategies and from (15.96\% to $30.85 \%)$ for the rest of cognitive strategies.

Table 4. Results of survey in percentages (five-point scale) $(\mathrm{N}=94)$

\begin{tabular}{|c|c|c|c|c|c|c|c|c|c|c|}
\hline \multirow[t]{2}{*}{ Scales } & \multicolumn{2}{|c|}{ Never } & \multicolumn{2}{|c|}{ Rarely } & \multicolumn{2}{|c|}{ Neutral } & \multicolumn{2}{|c|}{ Usually } & \multicolumn{2}{|c|}{ Often } \\
\hline & $N$. & $\%$ & $N$. & $\%$ & $N$. & $\%$ & $N$. & $\%$ & $N$. & $\%$ \\
\hline 1) Monitoring comprehension strategies & 18 & 3 & 99 & 15 & 76 & 12 & 156 & 24 & 309 & 46.9 \\
\hline 2) Cooperative learning strategies & 21 & 4.47 & 37 & 7.87 & 62 & 13.19 & 122 & 25.96 & 207 & 44.4 \\
\hline 3) Using graphic organizers & 6 & 3.19 & 16 & 8.51 & 4 & 2.13 & 51 & 27.13 & 95 & 50.53 \\
\hline 4) Answering comprehension questions & 4 & 2.13 & 1 & 0.53 & 9 & 4.79 & 51 & 27.13 & 107 & 56.92 \\
\hline 5) Summarizing strategies & 4 & 2.13 & 5 & 2.66 & 9 & 4.79 & 75 & 39.90 & 79 & 42.02 \\
\hline 6) Using multiple teaching strategies & 7 & 3.72 & 12 & 6.38 & 18 & 9.57 & 75 & 39.90 & 61 & 32.35 \\
\hline $\begin{array}{l}\text { 7) Techniques and approaches based on } \\
\text { cognitive scaffolding strategies }\end{array}$ & 27 & 9.57 & 27 & 9.57 & 33 & 11.70 & 108 & 38.30 & 41 & 14.54 \\
\hline 8) Use of Metacognitive strategies & 24 & 5.11 & 37 & 7.87 & 19 & 4.04 & 158 & 33.62 & 192 & 40.85 \\
\hline
\end{tabular}


Table 5. the purpose behind using scaffolding strategies

\begin{tabular}{|c|c|c|c|c|}
\hline \multirow[t]{2}{*}{ Scales } & \multicolumn{2}{|c|}{$\begin{array}{c}\text { To achieve } \\
\text { comprehension }\end{array}$} & \multicolumn{2}{|c|}{$\begin{array}{c}\text { To assess } \\
\text { comprehension }\end{array}$} \\
\hline & $N$. & $\%$ & $N$. & $\%$ \\
\hline 1) Monitoring comprehension strategies & 455 & 69.15 & 203 & 30.85 \\
\hline 2) Cooperative learning strategies & 345 & 73.40 & 120 & 25.53 \\
\hline 3) Using graphic organizers & 142 & 75.53 & 30 & 15.96 \\
\hline 4) Answering comprehension questions & 123 & 65.43 & 49 & 26.03 \\
\hline 5) Summarizing strategies & 117 & 62.32 & 55 & 29.26 \\
\hline 6) Using multiple teaching strategies & 123 & 65.43 & 48 & 25.53 \\
\hline $\begin{array}{l}\text { 7) Techniques and approaches based on cognitive } \\
\text { scaffolding strategies }\end{array}$ & 195 & 69.14 & 63 & 22.43 \\
\hline 8) Use of Metacognitive strategies & 365 & 77.66 & 79 & 16.81 \\
\hline
\end{tabular}

Table 6 indicates that a large amount of Non-native English language teachers use scaffolding strategies to enhance reading comprehension skills on purpose compared with few teachers who uses such strategies for granted. Interestingly, using monitoring comprehension strategies was the first rank among all scales (91.19\%). The least used scaffolding strategies among Non-native English language teachers is the multiple scaffolding strategies $(67.02 \%)$. Therefore, fewer than quarter of the sample of the study are unaware of the strategies they use; they use such strategies for granted or they use such strategies without being aware of the concept of these strategies. Some teachers teach the same way their teachers use thinking that it is the best.

Table 6. The degree of awareness in using scaffolding strategies

\begin{tabular}{llclc}
\hline Scales & $\begin{array}{c}\text { Teachers use strategies } \\
\text { consciously }\end{array}$ & $\begin{array}{c}\text { Teachers use strategies } \\
\text { unconsciously }\end{array}$ \\
\hline 1) Monitoring comprehension strategies & $\boldsymbol{N .}$ & $\boldsymbol{\%}$ & $\mathbf{N .}$ & $\%$ \\
2) Cooperative learning strategies & 600 & 91.19 & 58 & 8.81 \\
3) Using graphic organizers & 368 & 78.30 & 94 & 20 \\
4) Answering comprehension questions & 149 & 79.26 & 23 & 12.23 \\
5) Summarizing strategies & 151 & 80.32 & 21 & 11.17 \\
6) Using multiple teaching strategies & 152 & 80.85 & 20 & 10.64 \\
7) Techniques and approaches based on cognitive & 126 & 67.02 & 40 & 21.28 \\
scaffolding strategies & 204 & 72.34 & 41 & 14.54 \\
8) Use of Metacognitive strategies & & & & \\
\hline
\end{tabular}

\subsection{Descriptive statistics}

Two aspects of group behavior were considered here, the mean deviations for each variable. The mean score is the sum of all the survey scores divided by the total number of surveys used $(\mathrm{N}=94)$. The standard deviation is a "sort of average of the differences of all scores from the mean" (Brown, 1996, p.107).

Table 7 displays a summary of the findings along these lines. Interestingly, while mean scores reflected high percentages of using scaffolding strategies in teaching reading for helping their learners to develop their reading comprehension skills. Interestingly, (89.8\%) of Non-native English language teachers ask learners to answering reading comprehension questions. Again, the least used scaffolding strategies are those approaches based on cognitive scaffolding strategies such as the WebQuest and Reciprocal Teaching. Teachers do not adopt such approaches simply because they are not aware of them or they do not think it is fruitful. 
Table 7. Means and standard deviations of survey $(\mathrm{N}=94)$

\begin{tabular}{lllll}
\hline Scales & $\begin{array}{l}\text { Possible } \\
\text { Points }\end{array}$ & Mean & $\begin{array}{l}\text { Mean } \\
\text { Percentage }\end{array}$ & $\begin{array}{l}\text { Standard } \\
\text { Deviation }\end{array}$ \\
\hline 1) Monitoring comprehension strategies & 35 & 29.33 & $83.8 \%$ & 3.20 \\
2) Cooperative learning strategies & 25 & 20.90 & $83.6 \%$ & 6.92 \\
3) Using graphic organizers & 10 & 8.48 & $84.8 \%$ & 1.96 \\
4) Answering comprehension questions & 10 & 8.98 & $89.8 \%$ & 1.41 \\
5) Summarizing strategies & 10 & 8.56 & $85.6 \%$ & 1.51 \\
6) Using multiple teaching strategies & 10 & 7.98 & $79.8 \%$ & 1.96 \\
7) Techniques and approaches based on cognitive scaffolding & 15 & 10.78 & $71.87 \%$ & 2.82 \\
strategies & & & & \\
8) Use of Metacognitive strategies & 25 & 20.31 & $81.24 \%$ & 4.00 \\
\hline
\end{tabular}

\subsection{The t-test}

To reveal the extent to which differences found between two groups are due to chance, the t-test is performed by comparing the means of two groups and deciding whether the difference is statistically significant, given the size of the sample $(\mathrm{N}=94, \mathrm{df}=\mathrm{n}-2=92)$. Table 8 shows the $\mathrm{t}$-value $(\mathrm{T})$ obtained for each of the groups/variables compared (males and females). To check the t-values significance, any significance value less than (0.01) is an indication of statistical significance. Hence, all the differences compared are not statistically significant $(\mathrm{p}<0.01)$ except for both using multiple teaching strategies and Use of Metacognitive strategies.

Table 8. t-values of scales controlled by gender

\begin{tabular}{|c|c|c|c|c|c|c|}
\hline \multirow{2}{*}{ Scales } & & \multicolumn{2}{|c|}{$\begin{array}{l}\text { Levene's Test for } \\
\text { Equality of Variance }\end{array}$} & \multicolumn{3}{|c|}{ t-test for Equality of Means } \\
\hline & & $\mathrm{F}$ & Sig. & $\mathrm{t}$ & Df & $\begin{array}{c}\text { Sig } \\
\text { (2-tailed) }\end{array}$ \\
\hline \multirow{2}{*}{$\begin{array}{l}\text { 1) Monitoring comprehension } \\
\text { strategies }\end{array}$} & $\begin{array}{l}\text { Equal variances } \\
\text { assumed }\end{array}$ & 2.015 & .159 & 1.491 & 92 & .319 \\
\hline & $\begin{array}{l}\text { Equal variances } \\
\text { not assumed }\end{array}$ & & & 1.427 & 67.146 & .268 \\
\hline \multirow{2}{*}{$\begin{array}{l}\text { 2) Cooperative learning } \\
\text { strategies }\end{array}$} & $\begin{array}{l}\text { Equal variances } \\
\text { assumed }\end{array}$ & .725 & .397 & $-2.777-$ & 92 & .007 \\
\hline & $\begin{array}{l}\text { Equal variances } \\
\text { not assumed }\end{array}$ & & & $-2.192-$ & 33.379 & .035 \\
\hline \multirow{2}{*}{ 3) Using graphic organizers } & $\begin{array}{l}\text { Equal variances } \\
\text { assumed }\end{array}$ & 1.041 & .310 & $-1.003-$ & 92 & .319 \\
\hline & $\begin{array}{l}\text { Equal variances } \\
\text { not assumed }\end{array}$ & & & $-1.117-$ & 78.373 & .268 \\
\hline \multirow{2}{*}{$\begin{array}{l}\text { 4) Answering comprehension } \\
\text { questions }\end{array}$} & $\begin{array}{l}\text { Equal variances } \\
\text { assumed }\end{array}$ & 1.274 & .262 & $-.750-$ & 92 & .456 \\
\hline & $\begin{array}{l}\text { Equal variances } \\
\text { not assumed }\end{array}$ & & & $-.883-$ & 83.874 & .380 \\
\hline \multirow{2}{*}{ 5) Summarizing strategies } & $\begin{array}{l}\text { Equal variances } \\
\text { assumed }\end{array}$ & 1.962 & .165 & $-1.552-$ & 92 & .124 \\
\hline & $\begin{array}{l}\text { Equal variances } \\
\text { not assumed }\end{array}$ & & & $-1.787-$ & 82.521 & .078 \\
\hline \multirow{2}{*}{$\begin{array}{l}\text { 6) Using multiple teaching } \\
\text { strategies }\end{array}$} & $\begin{array}{l}\text { Equal variances } \\
\text { assumed }\end{array}$ & 10.138 & .002 & $-3.107-$ & 92 & .003 \\
\hline & $\begin{array}{l}\text { Equal variances } \\
\text { not assumed }\end{array}$ & & & $-3.741-$ & 83.716 & .000 \\
\hline 7) Strategies based on & Equal variances & 4.032 & .048 & $-3.107-$ & 92 & .654 \\
\hline
\end{tabular}


cognitive scaffolding strategies assumed

Equal variances not assumed

Equal variances assumed

8) Use of Metacognitive strategies
Equal variances not assumed

\begin{tabular}{|c|c|c|c|c|}
\hline \multirow{3}{*}{8.831} & & $-3.741-$ & 83.455 & .602 \\
\hline & .004 & $-2.416-$ & 92 & .18 \\
\hline & & $-2.714-$ & 79.639 & .008 \\
\hline
\end{tabular}

18

08

It is clear that there are no statistically significant differences between the mean scores of males and females in all scales except for using cooperative learning strategies, using multiple teaching strategies and Use of Metacognitive strategies which were in favor of female students. Hence, it can be argued that female students are interested in using varied strategies to scaffold students' learning. It seems also that females tend to encourage learners to think about their learning, the way they learn.

\subsection{Analysis of variance (ANOVA)}

To reveal the extent to which differences found between more than two groups are due to chance, ANOVA is performed by comparing the means of three or four groups (in the case under discussion, there are three groups representing qualification, years of experience and teaching load) and deciding whether the difference is statistically significant, given the size of the sample $(\mathrm{N}=94, \mathrm{df}=\mathrm{n}-2=92)$.

Close inspection of Table 9 reveals that no statistically significant differences can be detected in students' responses based on whether teachers only have got only the first university degree (BA) or that they have got postgraduate studies except in asking students to use summarizing strategies and orienting them on the best ways of summarizing techniques in favor for teachers with postgraduate studies.

Table 9. ANOVA controlled by qualification

\begin{tabular}{|c|c|c|c|c|c|c|}
\hline Scales & $\begin{array}{l}\text { Source of } \\
\text { Variance }\end{array}$ & $\begin{array}{l}\text { Sum of } \\
\text { Squares }\end{array}$ & $D f$ & $\begin{array}{l}\text { Mean } \\
\text { Square }\end{array}$ & $\boldsymbol{F}$ & Sig. \\
\hline \multirow[t]{3}{*}{ 1) Monitoring comprehension strategies } & $\begin{array}{l}\text { Between } \\
\text { Groups }\end{array}$ & 7.959 & 1 & 7.959 & \multirow{3}{*}{1.673} & \multirow{3}{*}{.199} \\
\hline & Within Groups & 437.75 & 92 & 4.758 & & \\
\hline & Total & 445.71 & 93 & & & \\
\hline \multirow[t]{3}{*}{ 2) Cooperative learning strategies } & $\begin{array}{l}\text { Between } \\
\text { Groups }\end{array}$ & .858 & 1 & .858 & \multirow{3}{*}{.018} & \multirow{3}{*}{.894} \\
\hline & Within Groups & 4072.48 & 92 & 48.481 & & \\
\hline & Total & 4073.256 & 93 & & & \\
\hline \multirow[t]{3}{*}{ 3) Using graphic organizers } & $\begin{array}{l}\text { Between } \\
\text { Groups }\end{array}$ & 4.987 & 1 & 4.987 & \multirow{3}{*}{1.299} & \multirow{3}{*}{.258} \\
\hline & Within Groups & 322.467 & 92 & 3.839 & & \\
\hline & Total & 327.453 & 93 & & & \\
\hline \multirow[t]{3}{*}{ 4) Answering comprehension questions } & $\begin{array}{l}\text { Between } \\
\text { Groups }\end{array}$ & 7.270 & 1 & 7.270 & \multirow{3}{*}{3.754} & \multirow{3}{*}{.056} \\
\hline & Within Groups & 162.684 & 92 & 1.937 & & \\
\hline & Total & 169.953 & 93 & & & \\
\hline \multirow[t]{3}{*}{ 5) Summarizing strategies } & $\begin{array}{l}\text { Between } \\
\text { Groups }\end{array}$ & 15.264 & 1 & 15.264 & \multirow{3}{*}{7.205} & \multirow{3}{*}{.009} \\
\hline & Within Groups & 177.946 & 92 & 2.118 & & \\
\hline & Total & 193.206 & 93 & & & \\
\hline \multirow[t]{3}{*}{ 6) Using multiple teaching strategies } & $\begin{array}{l}\text { Between } \\
\text { Groups }\end{array}$ & 9.552 & 1 & 9.552 & \multirow{3}{*}{2.520} & \multirow{3}{*}{.116} \\
\hline & Within Groups & 318.401 & 92 & 3.790 & & \\
\hline & Total & 327.953 & 93 & & & \\
\hline
\end{tabular}




\begin{tabular}{llllllll}
\hline 7) Strategies based & on cognitive & Between & 1.956 & 1 & 1.956 & & \\
scaffolding strategies & & Groups & & & & \\
& & Within Groups & 674.846 & 92 & 8.034 & .243 & .623 \\
& & Total & 676.802 & 93 & & & \\
8) Use of Metacognitive strategies & Between & .006 & 1 & .006 & & \\
& & Groups & & & & \\
& & Within Groups & 1362.52 & 92 & 16.220 & .000 & .985 \\
& Total & 1362.52 & 93 & & & \\
\hline
\end{tabular}

Table 10 reveals that no statistically significant differences can be detected in students' responses based on which years of experience except for the teacher's use of comprehension questions which naturally differs from experienced and inexperienced teachers based on their teaching practices.

Table 10. ANONA controlled by years of experience

\begin{tabular}{|c|c|c|c|c|c|c|}
\hline Scales & $\begin{array}{l}\text { Source of } \\
\text { Variance }\end{array}$ & $\begin{array}{l}\text { Sum of } \\
\text { Squares }\end{array}$ & $D f$ & $\begin{array}{l}\text { Mean } \\
\text { Square }\end{array}$ & $\boldsymbol{F}$ & Sig. \\
\hline \multirow[t]{3}{*}{ 1) Monitoring comprehension strategies } & $\begin{array}{l}\text { Between } \\
\text { Groups }\end{array}$ & 13.474 & 2 & 31.09 & \multirow{3}{*}{1.959} & \multirow{3}{*}{.147} \\
\hline & Within Groups & 313.005 & 92 & 4.215 & & \\
\hline & Total & 326.48 & 94 & & & \\
\hline \multirow[t]{3}{*}{ 2) Cooperative learning strategies } & $\begin{array}{l}\text { Between } \\
\text { Groups }\end{array}$ & 30.361 & & 15.180 & \multirow{3}{*}{.312} & \multirow{3}{*}{.733} \\
\hline & Within Groups & 4042.895 & & 48.710 & & \\
\hline & Total & 4073.256 & & & & \\
\hline \multirow[t]{3}{*}{ 3) Using graphic organizers } & $\begin{array}{l}\text { Between } \\
\text { Groups }\end{array}$ & 8.443 & & 4.221 & \multirow{3}{*}{1.098} & \multirow{3}{*}{.338} \\
\hline & Within Groups & 319.010 & & 3.843 & & \\
\hline & Total & 327.453 & & & & \\
\hline \multirow[t]{3}{*}{ 4) Answering comprehension questions } & $\begin{array}{l}\text { Between } \\
\text { Groups }\end{array}$ & 25.456 & & 12.728 & \multirow{3}{*}{7.311} & \multirow{3}{*}{.001} \\
\hline & Within Groups & 144.497 & & 1.741 & & \\
\hline & Total & 169.953 & & & & \\
\hline \multirow[t]{3}{*}{ 5) Summarizing strategies } & $\begin{array}{l}\text { Between } \\
\text { Groups }\end{array}$ & 5.020 & & 2.510 & \multirow{3}{*}{1.107} & \multirow{3}{*}{.335} \\
\hline & Within Groups & 188.189 & & 2.267 & & \\
\hline & Total & 193.209 & & & & \\
\hline \multirow[t]{3}{*}{ 6) Using multiple teaching strategies } & $\begin{array}{l}\text { Between } \\
\text { Groups }\end{array}$ & 1.912 & & .956 & \multirow{3}{*}{.243} & \multirow{3}{*}{.785} \\
\hline & Within Groups & 326.042 & & 3.928 & & \\
\hline & Total & 327.953 & & & & \\
\hline \multirow[t]{3}{*}{$\begin{array}{l}\text { 7) Strategies based on cognitive } \\
\text { scaffolding strategies }\end{array}$} & $\begin{array}{l}\text { Between } \\
\text { Groups }\end{array}$ & 2.258 & & 1.129 & \multirow{3}{*}{.139} & \multirow{3}{*}{.870} \\
\hline & Within Groups & 674.544 & & 8.127 & & \\
\hline & Total & 676.802 & & & & \\
\hline \multirow[t]{3}{*}{ 8) Use of Metacognitive strategies } & $\begin{array}{l}\text { Between } \\
\text { Groups }\end{array}$ & 13.243 & & 6.621 & \multirow{3}{*}{.407} & \multirow{3}{*}{.667} \\
\hline & Within Groups & 1349.280 & & 16.256 & & \\
\hline & Total & 1362.523 & & & & \\
\hline
\end{tabular}

Table 11 reveals that no statistically significant differences can be detected in teachers' responses based on the 
number of classes they teach every week. Astonishingly, teachers who teach only 6 classes a week are similar in their teaching performance to those teachers who teach 18 classes a week.

Table 11. ANONA controlled by teaching load

\begin{tabular}{|c|c|c|c|c|c|c|}
\hline Scales & $\begin{array}{c}\text { Source of } \\
\text { Variance }\end{array}$ & $\begin{array}{l}\text { Sum of } \\
\text { Squares }\end{array}$ & $D f$ & $\begin{array}{l}\text { Mean } \\
\text { Square }\end{array}$ & $\boldsymbol{F}$ & Sig. \\
\hline \multirow[t]{3}{*}{ 1) Monitoring comprehension strategies } & $\begin{array}{l}\text { Between } \\
\text { Groups }\end{array}$ & 14.891 & & 7.446 & \multirow{3}{*}{2.174} & \multirow{3}{*}{.120} \\
\hline & Within Groups & 311.59 & & 3.242 & & \\
\hline & Total & 326.48 & & & & \\
\hline \multirow[t]{3}{*}{ 2) Cooperative learning strategies } & $\begin{array}{l}\text { Between } \\
\text { Groups }\end{array}$ & 12.229 & & 6.115 & \multirow{3}{*}{.125} & \multirow{3}{*}{.883} \\
\hline & Within Groups & 4061.03 & & 48.93 & & \\
\hline & Total & 4073.26 & & & & \\
\hline \multirow[t]{3}{*}{ 3) Using graphic organizers } & $\begin{array}{l}\text { Between } \\
\text { Groups }\end{array}$ & 17.47 & & 8.74 & \multirow{3}{*}{2.339} & \multirow{3}{*}{.103} \\
\hline & Within Groups & 309.98 & & 3.74 & & \\
\hline & Total & 327.45 & & & & \\
\hline \multirow[t]{3}{*}{ 4) Answering comprehension questions } & $\begin{array}{l}\text { Between } \\
\text { Groups }\end{array}$ & 3.723 & & 1.862 & \multirow{3}{*}{.930} & \multirow{3}{*}{.339} \\
\hline & Within Groups & 166.23 & & 2.003 & & \\
\hline & Total & 169.95 & & & & \\
\hline \multirow[t]{3}{*}{ 5) Summarizing strategies } & $\begin{array}{l}\text { Between } \\
\text { Groups }\end{array}$ & .453 & & .226 & \multirow{3}{*}{.097} & \multirow{3}{*}{.907} \\
\hline & Within Groups & 192.78 & & 2.32 & & \\
\hline & Total & 193.21 & & & & \\
\hline \multirow[t]{3}{*}{ 6) Using multiple teaching strategies } & $\begin{array}{l}\text { Between } \\
\text { Groups }\end{array}$ & 8.006 & & 4.003 & \multirow{3}{*}{1.038} & \multirow{3}{*}{.359} \\
\hline & Within Groups & 319.947 & & 3.855 & & \\
\hline & Total & 327.953 & & & & \\
\hline \multirow[t]{3}{*}{$\begin{array}{l}\text { 7) Strategies based on cognitive } \\
\text { scaffolding strategies }\end{array}$} & $\begin{array}{l}\text { Between } \\
\text { Groups }\end{array}$ & 10.552 & & 5.276 & \multirow{3}{*}{.657} & \multirow{3}{*}{.521} \\
\hline & Within Groups & 666.250 & & 8.027 & & \\
\hline & Total & 676.802 & & & & \\
\hline \multirow[t]{3}{*}{ 8) Use of Metacognitive strategies } & $\begin{array}{l}\text { Between } \\
\text { Groups }\end{array}$ & 95.852 & & 47.926 & \multirow{3}{*}{3.140} & \multirow{3}{*}{.48} \\
\hline & Within Groups & 1266.671 & & 15.261 & & \\
\hline & Total & 1362.523 & & & & \\
\hline
\end{tabular}

\section{Discussion}

The scarcity of studies conducted to investigate teachers' use of scaffolding strategies in general and Non-native English language teachers as a special case makes the researcher's task to discuss results of the current studies with those of literature reviewed of the topic under discussion more difficult. Almost all literature reviewed has dealt with the impact of using scaffolding strategies for developing reading comprehension skills (e.g. Rahimi \& Ghanbari, 2011), enhancing computer skills (Yelland \& Masters, 2007), and metacognitive skills in reading (Royanto, 2012). Certain studies compared the effectiveness of scaffolding strategies used by two teachers to decide on which is more effective to adopt (Chi, 2007). Hence, the same thing that makes discussing the study results difficult also makes it distinguished.

In general, findings revealed that teachers tend to keep using scaffolding strategies to achieve better performance in reading comprehension. The outstanding result reached in the current study is that those teachers use such strategies in order to achieve comprehension rather than to assess comprehension. Interestingly, teachers keep 
asking students to answer comprehension questions to help them understand. Unfortunately, teachers' professional growth is somewhat low to the degree that they are not aware of modern approaches stemming from scaffolding strategies such as the WebQuest approach (Dodge, 1995) and reciprocal teaching (Palincsar \& Brown, 1984). Hence, deficits can be detected in-service professional growth for teachers that teachers are unaware of the modern trends in teaching and learning. Policymakers in the Ministry of Education should pay a due attention not only to hiring qualified teachers but also to the in-service professional development.

The lack of statically significant differences between the groups of teachers based on their experience (except for asking comprehension scale), their education level (except for using summarizing techniques) or teaching load refers to the homogeneity of the sample members, thus, their responses tend to fall into the same stream and focusing on the importance of certain strategies.

Logically, female teachers tend to be persistent in helping learners to be able to do each component of the task. In addition, they tend to be sure that learners can do the task after instructing them how to perform these bits or steps. Results of the study consolidate such premise; it is revealed that there are statistically significant differences between male and female teachers in three main scales; using cooperative strategies, using multiple strategies to help them practice skills, and using metacognitive skills in favor of female teachers.

\section{Conclusions}

Scaffolding is a metaphor for the interaction happening between expert and novice engaged in a problem-solving task or the adult controlling the elements of the task lying beyond the learner's capacity (Wood, 1988; Bruner \& Ross, 1976). Therefore, adults allow learners to concentrate upon and complete only those elements that are within his range of competence (HÜrsen, Ozcinar, Ozdami, \& Uzunboylu, 2011; Ferreira, 2007; Karahoca \& Uzunboylu, 2010). These strategies refer to adults helping children in a form of talk that supports a child in carrying out an activity (Bruner, 1986). New skills are developed in a social horizon, hence scaffolding strategies, in the light of sociocultural Theory, are viewed as a dialogic process by which one person assists another to perform a task or a component of a task he/she cannot do alone without such help (Ellis, 2004). Teachers' use of such strategies should be standardized and for a period of time not forever to maintain students' independence.

\section{Acknowledgement}

All thanks goes to all those who supervised me so as to make this work comes true, among them are Dr. Ali A. Qoura, Professor of TEFL, Mansoura University, Dr. Ahmed Hassan Seif, Professor of TEFL, Menoufyia University, and Dr. Azza Marsefy, Professor of TEFL, Zagazig University.

\section{References}

Askel-Williams, H., Lawson, M. J., \& Skzpiec, G. (2012). Scaffolding cognitive and metacognitive strategy instruction in regular class lessons. Instructional Science, 40, 413-443. https://doi.org/10.1007/s11251-011-9182-5

Attarzadeh, M. (2011). The effect of scaffolding on reading comprehension of various text modes on Iranian EFL learners with different proficiency levels. Social sciences and Humanities, 4(2).

Berk, L. (2002). Child development (5th Ed). Boston: Allyn and Bacon.

Brown, H. (2000). Principles of language learning and teaching. New Jersey: Prentice Hall.

Chastain, K. (1988). Developing second-language skills (3rd Ed.). Chicago: Harcourt Brace Jovanovich publishers.

Chi, F. M. (2007). Scaffolding EFL learns reading comprehension of texts. Department of Languages and Literature. National Chung Cheng University, Taiwan.

Clark, K., \& Graves, M. (2004). Scaffolding students' comprehension of text. International Reading Association, $58(6), 570-580$.

Clark, K. F., \& Graves, M. F. (2005). Scaffolding Students' comprehension of text: classroom teachers looking to improve students' comprehension should consider three general types of scaffolding. The Reading Teacher, 58(6), 570-46. https://doi.org/10.1598/RT.58.6.6

Dodge, B. (1995). Web Quest: a technique for Internet-based learning. Distance Educator, 1(2), 10-13.

Duffy, G.G. (2002). The case for direct explanation of strategies. In C. C. Block, \& M. Pressley (Eds.), Comprehension Instruction: Research-based best practices (pp. 28-41). New York: Guilford.

Ellis, R. (2004). Task-based language learning and teaching. English in China, 26, 43-46. 
Fan, Y. (2010). The effect of Comprehension Strategy instruction on EFL learners' reading comprehension. Asian social science, 6(8), 19-29. https://doi.org/10.5539/ass.v6n8p19

Farhady, H. (2005). Techniques for effective reading. Tehran: Rahnama Press.

Farhady, H. and Hessamy, G. R. (2005). Construct validity of L2 reading comprehension skills. Iranian Journal of Applied Linguistics, 8(2), 29-53.

Ferreira M., (2007). Constraints to peer scaffolding. Sao Paulo University, Brazil.

French, J. N., Ellsworth, N. J., \& Amoruso, M. Z. (1995). Reading and learning Disabilities. New York: Garland publishing Inc.

Gagne, E.D. (1985). The Cognitive Psychology of school learning. Canada: Little Brown and Company.

Gibbons, P. (2003). Mediating language learning: Teacher interactions with ESL students in a content-based classroom. TESOL Quarterly, 37(2), 247-273. https://doi.org/10.2307/3588504

Gunning, T. G. (1996). Reading instruction for all children. (2nd Ed). Need Heights: Simon \& Schuster Company.

Haghparast, Sh. \& Mall-Amiri, B. (2015). The comparative effect of two scaffolding strategies on intermediate EFL learners' reading comprehension. International Journal of Language learning and Applied Linguistics world, 8(2), 217-231.

Heilman, A. W.; Blair, T. R., \& Rupley, W. T. (1983). Principles and practices of training reading. (5th Ed.). Columbus: Charles Merril Publishing Company.

Henk, B. (2003). Reading reminder: A new tool for Scaffolding Strategic readers". Illinois Reading Council Journal, 31(2).

Huggins, G. E., \& Edwards, R. (2011). Scaffolding to improve reading comprehension and to write scholarly research sciences. Illinois Reading Council Journal, 1(16), 30-36.

Hughes, J. (2007). Teaching Language and Literacy. Retrieved $6^{\text {th }}$ June, 2015 from //faculty.uoit.ca/hughes/reading/reading process.html.

Huong, L. P. H. (2003). The meditational role of language teachers in sociocultural theory. English Teaching Forum, 14(3),31-35.

Hursen, C., Ozcinar, Z., Ozdamli, F., \& Uzunboylu, H. (2011). The communicative competences of students and teachers in different levels of education in north Cyprus". Asia Pacific Education Review, 12(1), 59-66. https://doi.org/10.1007/s12564-010-9120-2

Karahoca, D. \& Uzunboylu, H. (2010). Results of a citation analysis of the career counseling field from an African perspective. Journal of Psychology in Africa, 20(3), 463-470.

Karimi, L. \& Jalilvand, M. 2014. The effect of peer and teacher scaffolding on the reading comprehension of EFL learners in Asymmetrical and Symmetrical groups. The Journal of Teaching Language Skills, 5(4), $1-17$.

Koda, K. (2005). Insights into second language reading: A cross-linguistic approach. Cambridge: Cambridge University Press. https://doi.org/10.1017/CBO9781139524841

Koole, T., \& Elbers, E. (2014). Responsiveness in teacher explanations: A conversation analytical perspective on scaffolding. Linguistics and Education, 26, 57-69. https://doi.org/10.1016/j.linged.2014.02.001

Kozulin, A. (2004). Vygotsky's theory in the classroom: Introduction. European Journal of Psychology of Education, XIX(1), 3-7. https://doi.org/10.1007/BF03173233

Krause, K., Bochner, S., \& Duchesne, S. (2003). Educational psychology for learning and teaching. Australia: Thomson.

Lantolf, J. P., \& Thorne, S. (2006). Sociocultural theory and the genesis of second language development. Oxford: Oxford University Press.

Lantolf, J. P., \& Poehner, M. E. (2008). Introduction to sociocultural theory and the teaching of second language. In P. J. Lantolf, \& M. E. Poehner (Eds.), Sociocultural theory and the teaching of second language (pp. 1-30). London: Equinox.

Larkin, M. (2002). Using Scaffolded instruction to optimize learning. Council for Exceptional children. 
Levine, A., Ferenzo, O., \& Reves, T. (2000). "EFL academic reading and modern technology: How can we turn our students into independent critical readers?" TESLEJ, 4(4), 75-91.

Many, J. E. (2002). An exhibition and analysis of verbal tapestries: Understanding how scaffolding is woven into the fabric of instructional conversations". Reading Research Quarterly, 37, 376-407. https://doi.org/10.1598/RRQ.37.4.3

Many, J. E., Taylor, D. L., Wang, Y., Sachs, G. T., \& Schreiber, H. (2007). An examination of pre-service literacy teachers' initial attempts to provide instructional scaffolding". Reading Horizons, 48(1), 19-40.

McCurdy, N., Naismith, L. \& Lajoie, S. (2010). Using metacognitive tools to scaffolding medical students developing clinical reasoning skills. Cognitive and Metacognitive Educational Systems: Papers from the AAA1 Fall Symposium (FS -10-01).

McDevitt, T. M., \& Ormrod, J. E. (2002). Child development and education. Upper Saddle River, NJ: Merrill Prentice Hall.

Meyer, D. (1993). What is scaffolding instruction? Definitions, distinguishing features, and misnomers. In D. J. Leu, \& C. K. Kinzer (Eds.), Examining central issues in Literacy research, theory, and practice (pp. 41-53). Forty-second yearbook of the National Reading Conference. Chicago: National Reading Conference, Inc.

Ortlieb, E., \& Norris, M. (2012). Using the think-aloud strategy to bolster reading comprehension of science concepts. Current Issues in Education, 15(1), 1-10.

Palincsar, A. S., \& Brown, A. L., (1984). Reciprocal teaching of comprehension fostering and comprehension monitoring activities". Cognition and Instruction, 1, 117-175. https://doi.org/10.1207/s1532690xci0102_1

Pintrich, P. R. (2002). The role of metacognitive knowledge in learning, teaching, and assessing. Theory into Practice, 41(4), 219-225. https://doi.org/10.1207/s15430421tip4104_3

Pishghadam, R., \& Ghardiri, S. (2011). Symmetrical or asymmetrical scaffolding: Piagetian vs. Vygotskyan views to reading comprehension. Journal of Language and Literacy Education [online], 7(1),49-64.

Poorahmadi, M. (2009). The effect of employing scaffolding strategies and classroom tasks in teaching reading comprehension. Journal of Teaching English as a Foreign Language and Literature, 1(3), 87-106.

Pressley, M. (2002). Comprehension strategies instruction: A turn-of-the-century status report. In C. C. Block, \& M. Pressley (Eds.). Comprehension instruction: Research-based best practices (pp. 11-27). New York: The Guilford Press.

Pressley, M. (2002). Metacognition and self-regulated comprehension. In A. E. Farstrup, \& S. Samuels (Eds.), What Research Has to Say About Reading Instruction (pp. 291-309). Newark, DE: International Reading Association. https://doi.org/10.1598/0872071774.13

Pressley, M. (2002). Reading instruction that works: The case for balanced teaching (2nd Ed.). New York: Guilford Press.

Pressley, M., El-Dinary, P. B., Wharton-McDonald, R., \& Brown, R. (1998). Transactional instruction of comprehension strategies in the elementary grades. In D. H. Schunk, \& B. J. Zimmerman (Ed), self-regulated learning: From Teaching to self-reflective practice. New York: The Guilford press.

Rahimi, A., \& Ghanbari, N. (2011). The impact of teachers' Scaffolding on Iranian high school students' reading comprehension. Procedia: Social and Behavioral Sciences, 28, 1072-1075. https://doi.org/10.1016/j.sbspro.2011.11.193

Remi, A. V. C., \& Lawrence, W. (2012). Promoting sociolinguistic competence in the classroom zone of proximal development. Language Teaching Research, 16(1), 39-60. https://doi.org/10.1177/1362168811423340

Reza, Gh., \& Mahmood, D. (2012). Sociocultural theory and reading comprehension: The scaffolding of readers in an EFL context. International Journal of Research studies in Language Learning, 2(3), 67-80.

Rivers, M. W. (1988). Interactive language teaching. New York: Cambridge University Press.

Rodford, J., Bosanquet, P., Webster, R., \& Blatchford, P. (2015). "Scaffolding learning for independence: Clarifying teacher and teaching assistant roles for children with special educational needs". Learning and Instruction, 36, 1-10. https://doi.org/10.1016/j.learninstruc.2014.10.005

Roehler, L., \& Cantlon, D. (1997). Scaffolding: A powerful tool in social constructivist classrooms. In K. Hogan, \& M. Pressley (Eds.), Scaffolding student learning: Instructional approaches and issues (pp. 6-42). 
Cambridge, MA: Brookline Books.

Royanto, L. (2012). The effect of an intervention program based on scaffolding to improve metacognitive strategies in reading: A study of year 3 elementary school students in Jakarta. Procedia: social and Behavioral Sciences, 69, 1601-1906. https://doi.org/10.1016/j.sbspro.2012.12.105

Snow, C. (2002). Reading for understanding. Pittsburg: Rand Education.

Tahmasebi, S., \& Yamini, M. (2011). "Linking Task -based Language teaching and socio cultural theory: Private speech and scaffolding in Reading Comprehension". Advances in Language and Literacy studies, 2(1), 41-55. https://doi.org/10.7575/aiac.alls.v.2n.1p.41

Vygotsky, L. (1978). Mind in society: The development of higher psychological processes. Cambridge. MA: Harvard University Press.

Vygotsky, L. S. (1962). Thought and language. Cambridge, MA: MIT Press. https://doi.org/10.1037/11193-000

Wood, D., Burner, J. S., \& Ross, G. (1976). The role of tutoring in problem-solving. Journal of Child Psychiatry, 17(2), 89-100. https://doi.org/10.1111/j.1469-7610.1976.tb00381.x

Wood, G. (1998). Collocation-encouraging learner independence .In M. Lewis (Eds), Teaching collocation: further development in the lexical approach (pp. 28-46). Hove: Language Teaching Publications.

Yazdan P. M., \& Khan Mohammad, H. (2014). Socio-Cultural Theory and Listening Comprehension: Does the Scaffolding of EFL learners improve their listening comprehension. Theory and practice in Language studies, 4(11), 2389-2395.

Yelland, N., \& Masters, J. (2007). Rethinking Scaffolding in the information age. Computers \& Education, 48, 362-382. https://doi.org/10.1016/j.compedu.2005.01.010

Zohar, A., \& David, A. B. (2009). Paving clear path in a thick forest: a conceptual analysis of a metacognitive component. Metacognition Learning, 4, 177-195. https://doi.org/10.1007/s11409-009-9044-6

Zuengler, J., \& Miller, E. R. (2006). Cognitive and sociocultural perspectives: Two Parallel SLS worlds?. TESOL Quarterly, 40(1), 35-58. https://doi.org/10.2307/40264510

\section{Copyrights}

Copyright for this article is retained by the author(s), with first publication rights granted to the journal.

This is an open-access article distributed under the terms and conditions of the Creative Commons Attribution license (http://creativecommons.org/licenses/by/4.0/). 